and hearing and in some cases high accuracy can be obtained. We feel sure that if demand for a practical application of this device is sufficiently great it will develop into new applications just as photometry, telephony and television have developed. The first application is to measure leakage from gas mains. In this case a snout or 'trunk' is constructed of such a shape that it can conveniently be poked into crevices along the gas mains. The operator presses a button and if there is a leak a sample of the gas is inhaled quickly into a test chamber, where it flows over an electrically heated platinum wire and registers on the meter the percentage of gas present. We are told that the electric device can do something which the human nose cannot always do. It can tell infallibly the difference between town's gas and sewer gas.

\section{U.S. Industrial Research Laboratories}

A sixtr edition has recently been issued of the valuable list prepared by the National Research Council of the Industrial Research Laboratories of the United States (Washington, D.C.: National Research Council. Pp. 270. Paper cover, 2.50 dollars; cloth, 3 dollars). It consists of an alphabetical directory of commercial companies in the United States which maintain research laboratories, and is compiled from information obtained in each case from the director of research of the laboratory concerned. In asking for this information, it was pointed out that laboratories concerned merely with routine testing should not bo included, but it was left to the director of research to decide whether his Iaboratory came within this category or whether it could be said to conduct research. The present list comprises no less than 1,769 entries, each of which gives such data as officers-in-charge, address, fields of science or enginecring represented, research activities, publications, co-operative research-supported and number of personnel. Federal, State and municipal laboratories are not included, except the National Bureau of Standards, while those in educational institutions have been omitted unless they are directly supported by industry. Four indexes are provided : serial publications ; geographical distribu. tion; principal personnel ; and subjects of research.

\section{Spectrochimica Acta}

In May, Messrs. Springer of Berlin published the first number of Spectrochimica Acta, which is to be devoted to research in the domain of chemical spectral analysis (see NATure, 143, 468; 1939). The first number has 92 pages, $17 \mathrm{~cm}$. $\times 25.5 \mathrm{~cm}$., 82 of which are devoted to papers on changes of intensities in spectra of aluminium alloys (in German), quantitative analysis of solder, spelter, magnesium and aluminium alloys (in English), quantitative estimation of europium in samarium (in German), a new use of emission spectra in local spectro-analysis (in German), the use of the arc in spectro-analysis (in German). The remaining pages contain abstracts of papers published elsewhere prepared by more than forty specialists. The price of the number is 8.60 gold marks, which at the present rate of exchange is about 15s. and seems unduly high.

\section{Land-Speed Record}

Tine water-speed record set up on August 19 by Sir Malcolm Campbell has quickly been followed by a new record for speed on land. Mr. John Cobb, of London, in his Railton Red Lion motor-car, at Bonnevillo Salt Flats, Utah, is reported to have reached an average speed of 368.85 m.p.h. over a measured mile. The previous record of $357 \cdot 70$ m.p.h. was set up over the same course last September by Captain G. E. T. Eyston.

\section{Dundee and District}

A Notewortix and welcome feature of the "Scientific Survey of Dundee and District", prepared for the Dundee meeting of the British Association (Dundeo: B.A. Reception Room. 2s.) is tho inclusion of a new and very fine geological map of the country around Dundee. When it is remembered that the last official geological maps of most of this area dato from last century (Angus, 1884, and East Fife, 1889) and that the last semi-official map was that prepared for the 1912 meeting of the British Association in Dundee, the value of the new map will be at once realized. The map, although not an official publication, was prepared in the Scottish Office of H.M. Geological Survey, and inevitably shows many changes in mapping when compared with the 1912 edition. These changes aro in the main due to the revision work of the Survey officers in the Fife coalfields and to the researches of independent workers, as Allan, Balsillie, Cumming, and Walker. Geologists generally will welcome this new map. It is a pity that it has been bound into the volume instead of inserted in a bound-in envelope. A certain lack of uniformity of treatment is obvious in the natural science sections of the survey. This is due no doubt to lack of space, though it is very unfortunato that no room was found for mention of the geologists from Lyell, Hugh Miller, and Geikie onwards, whose labours have elucidated the geological problems of this very interesting part of Britain.

\section{Announcements}

Tre second International Congress of Eugenics will bo held at Bucharest on September 25-30 under the presidency of Prof. C. I. Parhon.

A LEAFLex of instructions for the correct application of the Schafer method of artificial respiration has been issued by the Royal Life Saving Society, 8 Bayley Street, Bedford Square, W.C.1, where it can be obtained free of charge.

Erratusi.-In Table 2 of the letter by Dr. L. Hahn and Prof. G. Hevesy entitled "Phosphatide Exchange between Plasma and Organs" published in Nature of July 29, p. 204, the percentago of organ phosphatide synthesized by the intestinal mucosa and the stomach have been interchanged; they should read: intestinal mucosa, 10.0 ; stomach, $4 \cdot 1$. 